\title{
Social Media and Alternative Discourse on Natural Hazard: A Case Study of Facebook Group 'Info Merapi'
}

\author{
MUZAYIN NAZARUDDIN \\ Universitas Islam Indonesia, Indonesia
}

\begin{abstract}
Existing research on social media in disaster management usually focuses on the role of social media in emergency management, while the roles of social media in normal times are rarely examined. This study discusses the content of the Facebook group 'Info Merapi', which is dedicated to disaster risk reduction, especially in the context of Mount Merapi periodic eruptions. The materials of this research are the content of the group over two months periods during the normal times of Mt. Merapi volcanic activities, namely 10 July to 10 August 2016 and 20 August to 20 September 2019. The material was analysed with a critical discourse analysis approach. In addition, this study has also interviewed the admin of the group. This study concludes that in the disaster-prone areas social media have important roles in communicating risk and maintaining the preparedness of local people to future hazards. This study also concludes that Info Merapi represents the traditional beliefs of local people to live in harmony, both in harmony with nature and in harmony with the spirits of Merapi. The group also represents the discourse of 'beautiful Merapi', which is in sharp contrast to the discourse of 'dangerous Merapi' as commonly displayed by the Indonesian mainstream media. Info Merapi proposes the local peoples' perspective, focusing on the long normal periods, rather than emphasizing the short eruption periods. Finally, Info Merapi also shows the dominance of modern state-sponsored knowledge about Mt. Merapi and its eruption among local residents on the slopes of Mt. Merapi.
\end{abstract}

Keywords: Social media, Info Merapi, alternative discourse, Merapi eruption, living in harmony.

\section{INTRODUCTION}

Indonesia is one of the disaster-prone countries, due to its geological, climatological, and social demographic aspects (Sudibyakto et al., 2012). From the geological aspect, the Indonesian archipelago is located in the Pacific Ring of Fire, also at the confluence of several tectonic plates. The social demographic aspects also play important roles in increasing social vulnerability to disasters. First, cultural, ethnic, and religious diversities, on the one hand, become a very significant asset, but on the other hand, could be a potential social hazard if not properly managed. Second, very high economic inequality and unequal access to various living resources have forced many groups of people to live in very vulnerable areas, such as hilly areas, riverbanks, waste disposals, or urban slums. Those who do not have access to adequate housing usually do not have access to other basic needs, so their ability to survive in disaster conditions is very weak (Sudibyakto et al., 2012, p. 16-18; Oliver-Smith, 1996, p. 315-316).

Considering these conditions, disaster education becomes a necessity, which should be carried out in various ways, including formal, informal and non-formal education channels. In this context, mass media have important roles in disaster education. Recently, in the Indonesian context, the role of disaster education is also conducted by social media 
platforms, especially social media that were initiated and managed by communities or institutions that are concerned with disaster risk reduction issues.

This research will discuss Info Merapi, a Facebook group dedicated to the local residents surrounding Mount Merapi, aimed to educate the locals and enhance their preparedness, especially in the context of the periodic eruption of Mount Merapi. This group is managed by several activists of disaster risk reduction on the slopes of Merapi, founded in 2011 , with a total membership of 44,319 in September 2019. This group is very active, almost every day it has some new information, whether in the form of photos, videos, written texts, or a combination of them. This group actively discusses Mt. Merapi and its surrounding environment from various aspects, from the very simple topic about the local weather to the serious information about Mt. Merapi eruption. The members of the group include academics, researchers, NGO activists, community media activists, volunteers, students, government officials, local residents, and others. Considering Mt. Merapi as the most active volcano in Indonesia with a very high frequency of eruptions (Surono et al., 2012), this group plays important role in educating local people and maintaining their awareness of the natural hazards embedded in their local environment.

The paper aims to uncover and analyse the discourse on natural hazards, especially about Mt. Merapi eruptions, in the Facebook group "Info Merapi", as well as to explain the roles of this social media platform in reducing disaster risk within the local communities. This paper would also aim to compare such discourse in the alternative media with the mainstream discourse as developed and disseminated by Indonesian mass media.

\section{LITERATURE REVIEW}

The existing previous studies have focused on the role of social media in disaster emergency management. Luna and Pennock (2018) who have reviewed the existing research on the use of social media and emergency management concluded that the adoption of social media applications in emergency management should be automatic. The use of social media in the disaster responses will provide some benefits, such as situational awareness, faster information diffusion, monitoring activities, and stakeholders' coordination. However, there are some challenges in the application of social media in disaster management, namely social challenges, technical challenges, regulatory frameworks, and social media monetization. While Alexander (2014) has identified seven uses of social media in emergencies, namely listening to public debate, monitoring situations, extending emergency management, crowdsourcing, and collaborative action, developing social cohesion, furthering causes, including charitable donation, and increasing research. The journal of Information Systems Frontiers has published a special issue on the exploitation of social media for emergency relief and preparedness, presenting some empirical papers on how various technologies, especially social media, work for enhancing pre-disaster preparedness, emergency events, and postdisaster relief operations (Ghosh et al., 2018).

However, the role of social media during normal times is very rarely discussed. This topic is indeed important, especially in the disaster-prone areas, in which the disasters happen periodically with high intensity. In such a type of society, normal time refers to the boundary between the past disaster and the future one. David Alexander (2014) who has reviewed the actual and potential use of social media in the emergency, disaster and crisis situations concluded that "One final point concerns the role of social media in the long periods dominated either by protracted recovery from major disasters or by mitigation (disaster risk reduction)" (Alexander, 2014, p. 730). While Rasmussen and Ihlen (2017) who have reviewed 
200 empirical studies on the issue of risk, crisis, and social media, brought out a similar conclusion, "A rather small part of the literature focuses on risk communication and social media. We can only speculate as to why crisis scenarios are studied much more often. Crises may be found more practical to study than risk situations in that they are perceived to be temporally and spatially limited events" (Rasmussen \& Ihlen, 2017, p. 12). Both of these authors have supported the study of the social media roles in the long normal periods, especially in communicating risk, reducing disaster risk, or guarding the recovery processes. Thus, this study would fulfil this academic call.

Focusing on the site of this study, Mt. Merapi is a 'well-used natural laboratory' (Voight et al., 2000). It has been much studied by various experts from volcanology, anthropology, geology, sociology, psychology, economy, and some other related fields. However, previous studies, especially related to the aspect of media or communication, are still very rare. To mention some of them, Lestari, Prabowo, and Wibowo (2012) have identified the model of disaster communication of Mt. Merapi eruption, especially from the government perspective. Roskusumah (2013) has studied communication processes in disaster mitigation. Nazaruddin and Habibi (2012) have focused on the role of public and alternative media during emergency responses. Nazaruddin (2017) has discussed the media representation of the 2010 Merapi eruption. While Purworini, Purnamasari, and Hartuti (2019) have applied chaos theory to describe crisis communication during the floods crisis in Klaten region, Indonesia.

\section{METHODOLOGY}

The main material of this research is content on Info Merapi Facebook Group. The research sample is every post and information in the group over two month periods, namely 10 July to 10 August 2016 (period 1) and 20 August to 20 September 2019 (period 2). For the purpose of comparison, the first period was chosen when the status of Mt. Merapi was 'normal active', while the second period was selected as the status of Mt. Merapi has raised into 'wary', or one level above the normal activities. In addition, data were also collected through in-depth interviews with group managers.

This research has applied a visual discourse analysis method, as outlined by Gillian Rose (2007, p. 141-171). To dismantle the discourse in visual text, Rose advises to observe and identify the rhetorical and social production of the text through the following steps: identify the main themes of the text, analyse the truth proposed by text, observe the complexities and contradictions in the text, and search for the omitted or invisible, as well as the visible, dimensions in the text.

Following Rose, this study has conducted the following steps of analysis. First, to identify the main topics of the text through an examination of the entire content that becomes the research object. In this step, the materials have been categorized with content analysis methods in order to find out what topics were discussed, with what perspective the topics were discussed, and who was involved in the discussions. Second, to conduct detailed analysis on some chosen topics, including the analysis of produced knowledge; justification strategy and truth effects; complexities and contradictions; subjects, both visible and invisible; power relations, including institution, location, and audience of the text; and other rhetorical strategies in the text. In this step, I did not analyse all themes, but only some of them, which were purposively selected as they were most commented on topics. 
According to Rose $(2007$, p. 157), visual discourse analysis is not a strict formal procedure and instead, it prioritises the analysis with 'fresh eyes' and 'great care for detail'. As a method, visual discourse analysis could borrow analysis tools from other methods, such as content analysis, composition analysis, semiotics, or psychoanalysis. I tried to keep this 'fresh eyes' through closely observing the detail of each content, especially using semiotic analysis. Also, to avoid under or over-interpretation, I used my first-hand experience as a local people who have stayed in the downslope of Mt. Merapi for more than a decade.

\section{RESULT AND DISCUSSION}

In the period of 10 July to 10 August 2016, this study found 384 posts, with an average of 12 13 posts in a day. Meanwhile, in the period of 20 August to 20 September 2019, this study found 307 posts, with an average per day is 10-11 posts. The posts can be categorized as follows:

Table 1: The categorization of topics in Info Merapi

\begin{tabular}{lcc}
\hline \multicolumn{1}{c}{ Topic } & \multicolumn{2}{c}{ Number } \\
& $\mathbf{2 0 1 6}$ & $\mathbf{2 0 1 9}$ \\
\hline Weather information & 91 & 43 \\
The current status of Merapi & 2 & 74 \\
Picture of Merapi & 43 & 38 \\
Thanks from the new member & 79 & 8 \\
Local event & 35 & 13 \\
Event promotion & 14 & 5 \\
Picture of local environment & 10 & 6 \\
Islamic da'wah & 7 & 7 \\
Criminality & 5 & 9 \\
Earthquake information & - & 37 \\
Forest fire & - & 22 \\
Blood donors & 31 & - \\
Others & 67 & 45 \\
Total & $\mathbf{3 8 4}$ & $\mathbf{3 0 7}$ \\
\hline
\end{tabular}

Table 2: The most commented topics in Info Merapi

\begin{tabular}{lcc}
\hline \multicolumn{1}{c}{ Topic } & Number of posts having more than $\mathbf{1 0}$ comments \\
& $\mathbf{2 0 1 6}$ & $\mathbf{2 0 1 9}$ \\
\hline Weather information & 12 & 16 \\
Picture of Merapi & 10 & 16 \\
Current status of Merapi & 2 & 10 \\
Forest fire & - & 18 \\
Local event & 11 & 8 \\
Picture of local environment & 6 & 4 \\
Criminality & 3 & 2 \\
\hline
\end{tabular}

We may infer some insights from the two tables above. First, in 2016, Info Merapi has a fairly high number of incoming new members. There were 79 posts of saying thanks to the new members in July-August 2016. Meanwhile, in August-September 2019, the addition of new members was only about 8 people. Most likely the number of new members in those periods was more than that because there could be many new members who did not express their greetings or thanks openly in the group. Second, weather information, the current status of Merapi, and photos of Merapi are some of the most shared and commented topics that I will further discuss in the next sections. 
Third, there are some group members who always send the same type of information almost every day. Table 1 shows that there were 31 posts regarding the need for blood donors, all of them done by a member named Ifa Raharjo. It seems that Ifa is a volunteer of a particular institution in this field, using Info Merapi to disseminate the information about blood needs. In 2019, earthquake information was almost entirely conveyed by a member with the account name 'Gogon' by quoting the official information from BMKG (Badan Meteorologi, Klimatologi dan Geofisika - Centre of Meteorology, Climatology, and Geophysics). Likewise, the latest status of Merapi is dominated by 'RM Rhama', a search and rescue volunteer, who updates the current status of Merapi almost every day by quoting information from BPPTKG (Balai Penyelidikan dan Pengembangan Teknologi Kebencanaan Geologi - Centre of Research and Development of Geological Disaster Technology).

In addition, Kiswanto Adinegara, a citizen journalist, in 2016, often shared the community activities taken from 'Karangnongko.Klaten.info'. For example, on 22 July 2016 (9.47), he shared a story entitled "Kalijodo akan jadi ajang festival layang-layang Jateng-DIY Kalijodo will become the location of kite festival of Central Java and Yogyakarta Special Province". While on 23 July 2016 (9.29), Kiswanto shared news under the title "Rawan kecelakaan, warga pasang rambu peringatan di jalan poros Desa Kadilajo - Prone to a traffic accident, locals installed warning sign at Kadilajo village road". In 2016, the contents categorized as 'local events' was dominated by Kiswanto. In 2019, Kiswanto actively shared photos of Merapi from various locations. This behaviour was also carried out by several other group members, namely sharing similar information according to their interests or preferences.

The Landscape Photos of Merapi: Representing Living in Harmony with the Volcano The most often shared photo in this Facebook group is landscape photographs of Merapi, displaying humans, settlements, or other cultural artifacts as the foreground and Mount Merapi as the background. Some of the photos were just shared without any additional information, while some others were uploaded with additional information about weather conditions, the current status of Merapi, and others.

Almost all photos display the beauty of Merapi landscape, taken from various sides at certain moments. These photos, like most panorama photos, show the beauty of the captured panorama. Aesthetic factors become the dominant feature of these panoramic photos. The composition of the photo in such a way was carefully considered by the photographer. Usually, the sender will include a brief description of the photo. For example, Rossalina Rosa (2 August 2016, 9.45) shared a photo and wrote, "Merapi tampak gagah terlihat dari Kalikuning Sidorejo - Merapi looks dashing from Kalikuning Sidorejo". While Kiswanto Adinegara on August 23, 2019 (07.10) posted a photo and wrote:

Merapi

Seen quite clearly from Embung Bimomartani Ngemplak Sleman Yogyakarta

Sunny weather, normal people activity

Friday Kliwon, 08-23-2019

\# keep aware and stay alert 
This discourse of 'beautiful Merapi' is very supported by group members. A member of the group, Ijan Poni Jan (30 July 2016, 8.30) wrote, "Melihat foto foto postingan sedulursedulur di info Merapi jujur saja bikin hati ini kangen dengan Merapi. Ra kroso meh seperempat abad meninggalkan lereng Merapi - Seeing the photos you have posted in this group makes me miss Merapi. It is almost a quarter of a century I have left Merapi". The Merapi landscape photos also received the most responses from group members. Interestingly, some members respond to the photos by displaying another landscape photo taken from different locations.

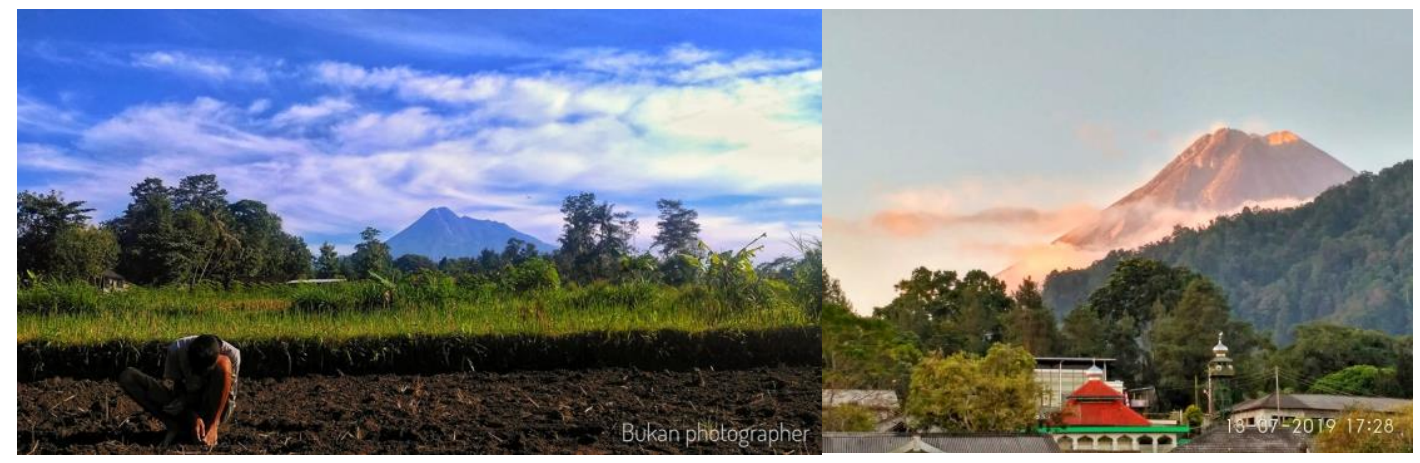

Picture 1: Landscape photos of Merapi

The landscape photos fundamentally show certain worldviews. First, the balance between the foreground (rice fields, roads, settlements, etc.) with the background (Merapi) shows an equally important position in the photo, cannot be eliminated either. The balanced composition between the two, not emphasizing one of them, represents the balance between humans and nature, between Mt. Merapi and local people. It strongly represents the way of life of local people on the slopes of Merapi who believe that they should keep the harmony of nature. For the locals, nature lives water, soil, plants, they live. In this perspective, the human is just a subject on the earth, which must live in harmony with other subjects for the balance of the ecosystem. The locals periodically perform certain rituals in order to maintain the harmony between human and nature (Nazaruddin, 2013, p. 24-25).

Second, the composition of the top and bottom, where the volcano usually occupies the top of the photo, while buildings, roads, or humans occupy the bottom of the photo. Kress and van Leeuwen (1996, p. 199) have noted that top-down composition in the visual text is very important, representing certain fundamental dichotomies, such as sacred versus profane, ideal versus real, or other dichotomies according to the local context. In these landscape photos, the top-down composition represents the sacred versus profane dichotomy, in which Merapi is believed as a symbol of sacred power, while the human and their culture are symbols of the profane dimension (Nazaruddin, 2017, p. 314).

This belief, Merapi as a sacred power and human as a profane dimension, is deeply rooted in the traditional beliefs about Mt. Merapi among local people. They believe that Merapi is not just a mountain, but also a kingdom of spirits, with a palace in its crater. The peak of the volcano and its upper part is the place where the spirits live, while the lower slopes of the mountain are human habitation. They also believe that they should live in harmony with the spirits. By carrying out certain rituals and avoiding traditional taboos, the locals feel safe living on the slopes of the volcano because they have expressed a good attitude of harmonious living with the spirits (Triyoga, 2010; Schlehe, 1996; Dove, 2008; Donovan, 2010; Lavigne et al., 2008). Thus, living in harmony on the slopes of Merapi, both in 
harmony with nature and in harmony with the spirits, is believed by local people for a long time, passed down through generations. In this perspective, the photos in Info Merapi represent this belief.

It is very different from photographs in the mainstream media, which always discourse the horrors of Merapi eruptions. Of course, it is due to the mainstream media displaying the Merapi pictures only in the emergency conditions when they are reporting the eruption. They presented news about Merapi only when an eruption occurs. During the crisis periods, mainstream media were accustomed to displaying close-up photos of the peak being erupted, creating an impression of the extraordinary horror of the Merapi eruption (Picture 2). On the contrary, they very rarely display Merapi photos in normal conditions. They mainly discourse that Merapi is a very dangerous volcano, and thus its slopes are not suitable for human settlements (Nazaruddin, 2017, p. 313). Thus, in this context, Info Merapi presents a counterdiscourse. Photographs of Merapi in Info Merapi display the beauty of this mountain, in contrast to the image of danger and horror.

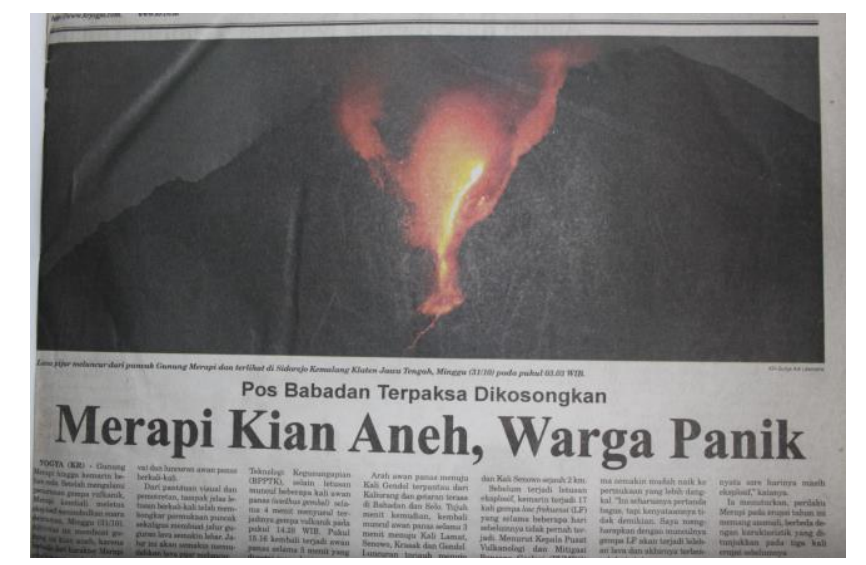

Picture 2: Eruption images on Indonesian mainstream media

Furthermore, this actually shows a different perspective between local residents on the one hand and the government and mainstream media on the other hand. Several studies have shown that the conflicts between government and local residents on the slopes of Merapi are caused by this difference perspective (Dove, 2008). On the one hand, the government always emphasized the eruption period. The government's attention to the residents focused on the eruption period, because of which they usually concluded that residents should be relocated to safer areas. While mainstream media always placed the government as the main source when they are reporting the eruption crisis. On the other hand, local people emphasized normal periods, which are much longer than the emergency periods that only last for a few weeks every three to five years (Nazaruddin, 2013, p. 44). In this conflict of perspective, Info Merapi group is in line with the locals' perspective, while the mainstream media support the government's perspective.

Nabih Basyir, a group member, on 29 July 2016 (9.58) displayed and compared two pictures of Merapi forest, a photo of a burnt forest due to eruption and a photo of green forest (Picture 3). The photo implies that Merapi can be dangerous, the forest can be burned down, but Merapi will return everything, the forest will return green and beautiful. It confirms the locals' belief that they do not see the eruption as a disaster, or as a mere disaster, but rather as a blessing. Volcanic ash from the eruption will be a natural fertilizer that returns soil fertility. Besides, volcanic dust will also re-fertilize the Merapi forest, growing dense grass that 
will be the staple food for cattle (Triyoga, 2010, p. 92-93). In that perspective, the eruption is an important moment for local residents, resting time for them, letting nature through its own mechanism restore the ecological balance. In this sense, the eruption is an integral part of local peoples' lives. In times of emergency, they will flee to safer places. However, after that, they will return to their village. For them, the long safe and fertile period from one eruption to the next is much more important, compared to a short crisis period which is only a few weeks or months. Dove (2008, p. 329) has stated "Villagers living on Merapi have developed a system of religious belief, and a system of agro-ecological practices, that 'domesticates' the volcanic hazard".

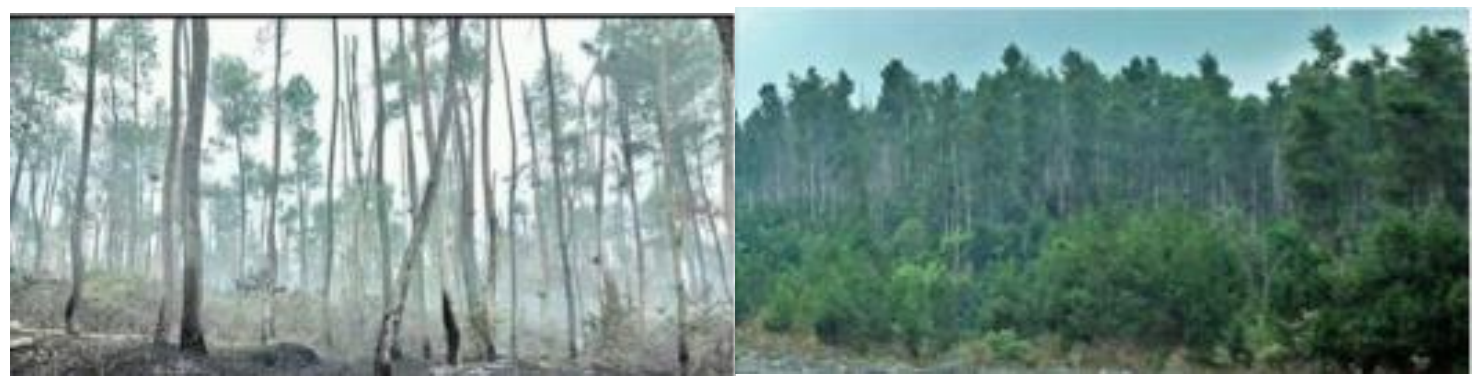

Picture 3: The images of Merapi forest in Info Merapi

The Current Status of Merapi: Representing The Dominance of the Modern Knowledge In 2016, during a month observed period, the Merapi activity report from BPPTKG was distributed twice, namely, the report on the 8-14 July 2016 period, posted by lyan Shorobayan on 15 July 2016 and another report shared by Totok Sondong Hartanto on 19 July 2016. Meanwhile, in the period of August-September 2019, the information on the current status of Merapi dominates this group, almost every day we can find updates on the status of Merapi. The information is almost entirely from the official source, namely BPPTKG. There was only two pieces of information about the condition of Merapi based on direct observation.

The sharp increase in the number of Merapi status update was due to some aspects. First, in 2016, Merapi status was 'normal active', while in 2019 Merapi status was 'wary'. In this wary status, BPPTKG more intensively published the latest update of Merapi. Second, the official website of BPPTKG presents real-time CCTV records from several Merapi observation posts. Some CCTV focuses on the peak of Merapi, while some others display another important area, such as the river area which is normally traversed by materials of the eruption. These CCTV records can be easily accessed and shared. RM Rhama, a group member as well as a search and rescue volunteer, almost everyday shares this CCTV footage to the group.

There are several types of content regarding the current status of Merapi. The most dominant is brief information about the current status of Merapi by quoting BPPTKG, accompanied by CCTV records (Picture 4) or seismograph records (Picture 5). Some users quote the current status of Merapi from BPPTKG, added with Merapi pictures, usually landscape photos taken by themselves. Meanwhile, some users share information from mainstream online media about the current status of Merapi. 


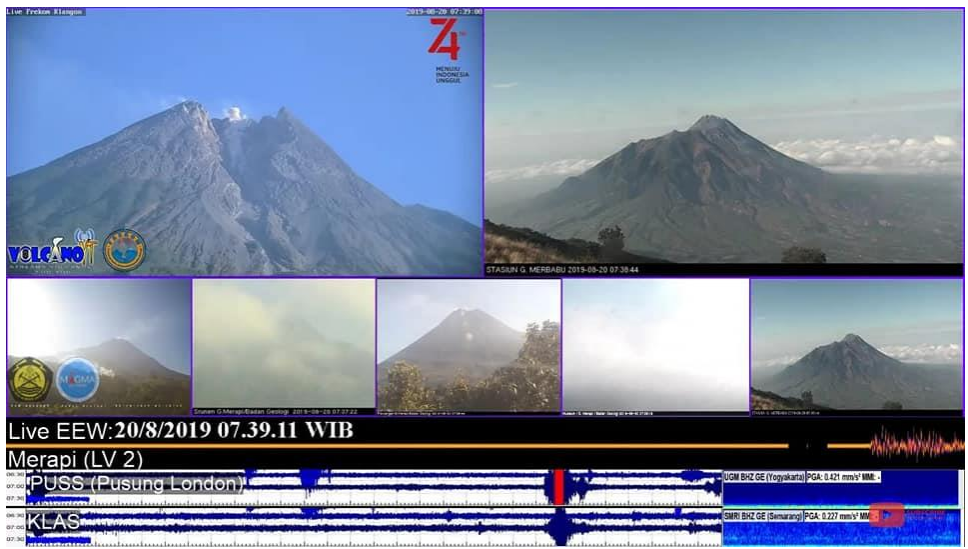

Picture 4: CCTV records from BPPTKG website

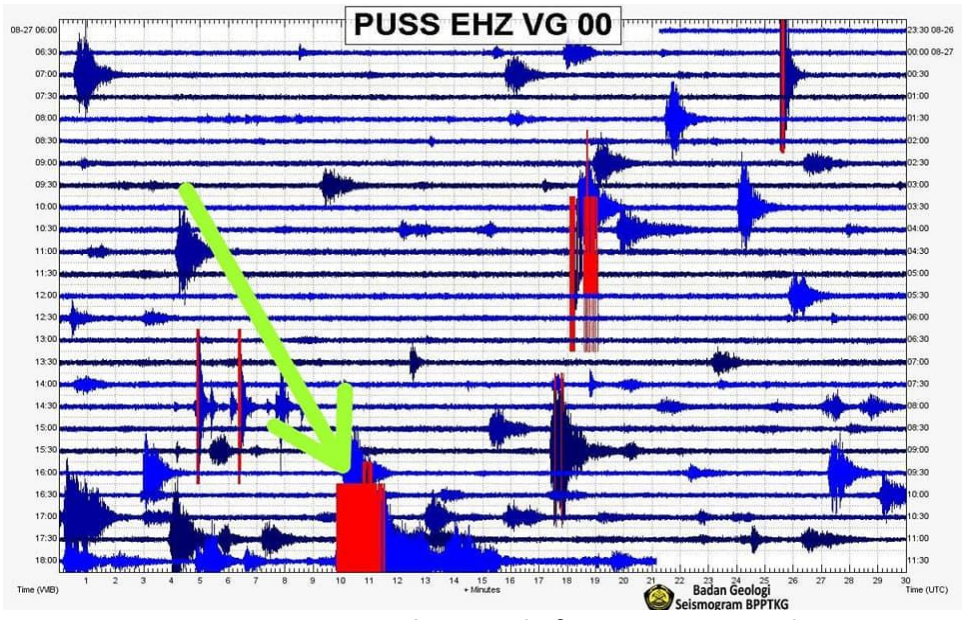

Picture 5: Seismograph records from BPPTKG website

Official brief information on the current status of Merapi from BPPTKG usually contains the following aspects: 1). Time of observation, usually mention the date, time, and duration in detail, 2). Source of observation, for example, CCTV monitoring or seismograph recording, 3). The event happened, such as lava falls, 4). The intensity of the event, for example, 10 times of lava falls, 5). The direction of the event, for example, upstream of Kali Gendol with a sliding distance of several meters. 6). Consequences or conclusions, for example, 'wary status'. The following are examples of the brief information from BPPTKG shared in the group:

Activity Report Mt. *Merapi* observation period_20/8/2019 at 06:00 to 18:00 WIB_ watched from CCTV_12 times lava falls_ with sliding distance *350$800 m^{*}$ upstream K. Gendol

The full report can be seen at https://t.co/WEs0sX6UDD

*wary status* since May 21, 2018

* BPPTKG*

(https://twitter.com/BPPTKG/status/1163775369784123393?s=17) 
Hot clouds falls Mt. \#Merapi occurred on August 27, 2019 at 18:09 WIB. Hot clouds falls are recorded on the seismogram with max amplitude. $70 \mathrm{~mm}$ and duration \pm 198.90 seconds. Sliding distance is $2,000 \mathrm{~m}$ upstream of Gendol River.

\#wary status since May 21, 2018 https://t.co/Pt1Z5b71hz

The type of photo that usually added to the Merapi status update is a close up photo of the peak of Merapi, taken from CCTV records from BPPTKG website. Some of them display the close-up images of the peak, clearly showing the release of fire, materials, or smoke (Picture 6). These photos are similar to the mainstream media photos (Picture 2), representing the danger of Merapi eruption. Interestingly, it seems that the photos are becoming as normal images for the group members, as well as for the local residents on the slopes of Merapi in general. The photos did not cause social panic among local residents anymore. Thus, the real-time CCTV record and its intensive dissemination seem to have succeeded in installing a new understanding to the local residents: that is how the peak of Merapi when it erupts and viewed closely.

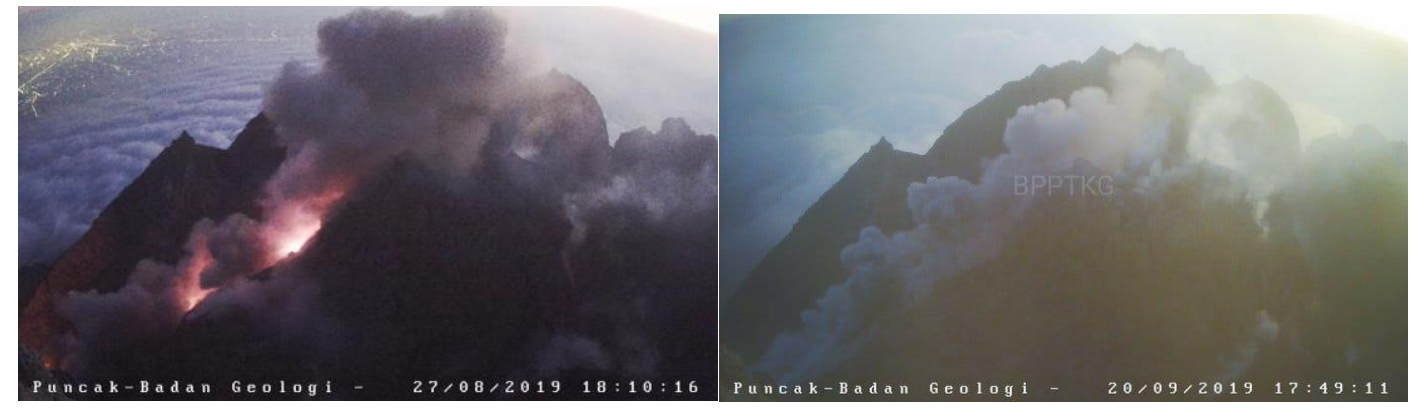

Picture 6: Eruption images from CCTV records

This phenomenon shows that young people on the slopes of Merapi trust the information from BPPTKG about the current status of Merapi, as well as rely on this information for decision making, such as the need to evacuate or not. It also shows that members of this group have mastered modern literacies about Mount Merapi, for example knowing the boundary between safe and unsafe distances of material falls. Most importantly, it shows the dominance of modern state-sponsored knowledge about Mt. Merapi and its eruptions among the local residents on the slopes of Merapi. Further, it indicates an on-going social change on the slopes of Merapi. In the previous periods, especially in the 1990s, local people on the slopes of Mt. Merapi still believed to the traditional knowledge system to guide them during the eruption times (Triyoga, 2010; Schlehe, 1996; Dove, 2008; Dove, 2010).

The Weather Information: Representing The Marginalization of the Traditional Knowledge The weather information is another type of information most frequently uploaded and commented by group members. They can be categorized into two groups, namely official information from the government institutions and information based on empirical experiences.

First, official information from the government agencies was dominated by the information from BMKG and BPPTKG. In addition to weather information, updates from BMKG about earthquakes in various parts of the Indonesian archipelago are always shared by one of the group members (Table 1). The official information is often in the form of quite long 
explanations, sometimes accompanied by scientific terms and satellite imagery photos. For example, the weather forecast information consists of 4 paragraphs, titled 'Waspada potensi hujan lebat dan gelombang tsunami di Selatan Jawa (10-14 Juli 2016) - Beware to the potential for heavy rains and tsunami waves in South Java (10-14 July 2016)', shared by Kang Kris (9 July 2016), Prince Ru (10 July 2016), and Totok Sondong Hartanto (15 July 2016). This information was launched by the BMKG Public Meteorological Centre. The following is an example of short weather information sent by lyan Shorobhayan on 20 July 2016:

\section{\# Weather Info \# Merapi \\ * 14.13 via PGM Babadan \# Merapi is foggy, temperature $21.6^{\circ} \mathrm{C}$, humidity $81 \%$ rh, pressure $872.3 \mathrm{hpa}$, calm wind, cloudy weather}

Via @BPPTKG

Second, the weather information is based on the sender's empirical experience. Usually, the information provided is quite short, reporting the weather conditions at a certain location where the sender stays, for example, 'Ngemplak starts raining' (Denis Novita, 15 July 2016, 18.13), 'Northern part of Manisrenggo starts raining' (Gufit Imuet, 17 July 2016, 21.06), or 'Umbulharjo Cangkringan is heavy raining and accompanied by lightning' (Rachel Angelin, 17 July 2016, 20.57). Often, this weather info is also accompanied by a photo that visualizes the weather condition. In addition to providing weather information, sometimes some members ask about weather conditions, for example, Tanggo India Rossa (15 July 2016, 19.26) asked, 'Is that true that tonight the Jogja city centre is raining? Please let me know'.

The two types of weather info actually show two methods of thinking among Info Merapi members, as well as among the locals on the slopes of Mt. Merapi in general. The first model is the empirical experience, the second model is scientific authority. The first model, as seen from weather information based on empirical experience, is actually rooted in the traditional knowledge model of Javanese culture. The model is commonly named as 'ilmu titen', referring to the traditional method of knowing through careful, diligent and continuous observations to the environment, from one phenomenon to another phenomenon, in order to find certain patterns or relationships between phenomena. Then, this knowledge is passed down from generation to generation, usually reinforced by daily experience (Nazaruddin, 2013, p. 25). This method starts with a simple step, namely observations and experiences of the environment, as exemplified by weather information in Info Merapi. It is also used by local residents of Merapi to interpret Merapi's activities, especially during eruption periods. They will be very careful with natural signs that usually occur before the eruption, such as animals coming down from the forest, eagles flying in circles, the air getting hotter, or others.

While the second model, scientific information is obtained from the state institutions and based on modern knowledge about nature. In this case, BPPTKG and BMKG are the state apparatus that guarantee the application of modern science to understand nature, as well as disseminate the scientific knowledge and information to the public.

Info Merapi shows combination and contestation as well of these two methods among local residents on the slopes of Merapi. They use official information from the government, but also use empirical observations. However, Info Merapi also shows that the dominance of modern scientific knowledge is getting stronger from day to day. On the other hand, 'ilmu titen' as a traditional method is increasingly abandoned. 
An interesting example from Info Merapi illustrates this scientific knowledge dominance. A member uploaded a photo of a straight-line cloud on 24 August 2019. The photo has received many responses, a total of 62 comments. Some people said that it was just a plane smoke. However, some people said that it was an earthquake sign. For example, someone wrote, 'Biasane njur ono lindu - Usually it will be an earthquake'. Another member wrote longer, "Kalau benar-benar nggaris itu awan gempa. Saya sudah berkali-kali mengamati setelah ada awan gempa tidak lama lagi terjadi gempa bumi - If the cloud is straight-lined then it is an earthquake cloud. I have repeatedly observed that after an earthquake cloud then an earthquake will come soon". But, there were so many members who refute this opinion for various reasons, including no scientific basis for linking the shape of clouds with earthquakes. Some even blaspheme this opinion with the theological argumentation, saying that the person who relates the cloud with the earthquake was doing a big sin as he was acting as God who has absolute power to decide what will happen in the future. Another member calls them 'shamans'. As a result, people who try to interpret the natural signs based on their empirical observations or 'ilmu titen' are marginalized.

This finding is somehow different from some previous studies which stated that local residents lack trust in the modern knowledge campaigned by the government (Dove, 2008; Dove, 2010; Lavigne et al., 2008). However, previous studies usually discuss the eruption in 1994 or 2006, or even the period before that, while this study discusses the phenomena after the 2010 eruption. Thus, these findings differences reinforce the early conclusion that ongoing social change is taking place in the local communities on the slopes of Mt. Merapi.

\section{CONCLUSION}

Info Merapi is a Facebook group that actively discusses various aspects of social, cultural, and environmental issues around the slopes of Mt. Merapi. The current status of the volcano, the weather information, and the landscape photos of Mount Merapi are the most popular topics that are most frequently shared and commented by group members. This group has enhanced the awareness of its members to the current status of their volcano and the potential future eruptions. Theoretically, we may infer that in the disaster-prone areas social media have important roles in communicating risk and maintaining the awareness of local people to the future natural hazards. This theoretical conclusion implies for future studies to examine in more detailed and measurable procedures, especially with quantitative methods, how various platforms of social media take roles in reducing disaster risk, promoting disaster education, and enhancing community resilience among disaster-prone societies. This issue should be empirically studied through analysing the use of various platforms of social media, whether in the emergencies and normal periods.

The landscape photos of Merapi in this group represent the discourse of 'beautiful Merapi', in contrast to the discourse of the 'dangerous Merapi' as usually promoted by the mainstream mass media. The mainstream media broadcast news about Merapi only when the eruption occurs. They usually present the eruption news on their headlines, accompanied by the big size photos closely displaying the peak that is being erupted, sending the message of terrible and deadly eruptions. They very rarely display Merapi photos in the normal conditions. In this context, Info Merapi presents a counter-discourse, promoting the image of a beautiful landscape of Merapi.

The photos in Info Merapi also represent the idea of living in harmony with nature, as well as with the spirits who also inhabit nature. The photos represent the idea that Mount Merapi is a symbol of sacred power, while the human and their culture are symbols of profane 
dimensions. This idea of living in harmony is believed by the locals for a long time and passed down through generations.

Info Merapi also shows the combination, as well as the contestation, of two knowing methods among local residents on the slopes of Merapi. The old method is based on daily direct observation, commonly called 'ilmu titen', while the new method is based on modern science and technology, which is mainly sponsored by the state. Furthermore, this study concludes that modern state-sponsored knowledge has recently dominated the locals' perspective on their volcano and the surrounding environment. Nowadays, young people on the slopes of Mt. Merapi rely on the official information from BPPTKG for their communal decision-making. Furthermore, this phenomenon indicates certain cultural shifts within the local communities on the slopes of Mt. Merapi, which should be further investigated by future research.

\section{ACKNOWLEGDEMENT}

The author is very grateful to the Department of Communication, Universitas Islam Indonesia, for funding this research.

\section{BIODATA}

Muzayin Nazaruddin is a lecturer at the Department of Communication, Universitas Islam Indonesia. He is recently a PhD student at the Department of Semiotics, University of Tartu, Estonia. His academic interests include disaster studies, environmental communication, and environmental humanities. Email: muzayin.nazaruddin@uii.ac.id 


\section{REFERENCES}

Alexander, D.E. (2014). Social media in disaster risk reduction and crisis management. Science and Engineering Ethics, 20, 717-733. doi: 10.1007/s11948-013-9502-z

Donovan, K. (2010). Doing social volcanology: Exploring volcanic culture in Indonesia. Area, 42(1), 117-126.

Dove, M. R. (2008). Perception of volcanic eruption as agent of change: On Mt. Merapi volcano, Central Java. Journal of Volcanology and Geothermal Research, 172, 329-337.

Dove, M. R. (2010). The panoptic gaze in a non-western setting: self-surveillance on Mt. Merapi volcano, Central Java. Religion, 40(2), 121-127.

Ghosh, S., Ghosh, K., Ganguly, D., Chakraborty, T., Jones, G. J. F., Moens, M. F., \& Imran, M. (2018). Exploitation of social media for emergency relief and preparedness: Recent research and trends. Information Systems Frontiers, 20, 901-907. doi: https://doi.org/10.1007/s10796-018-9878-z

Kress, G., \& van Leeuwen, T. (1996). Reading images: The grammar of visual design. London \& New York: Routledge.

Lavigne, F., De Coster, B., Juvin, N., Flohic, F., Gaillard, J., Texier, P., Morin, J., \& Sartohadi, J. (2008). People's behaviour in the face of volcanic hazards: Perspective from Javanese communities, Indonesia. Journal of Volcanology and Geothermal Research, 172, 273287.

Lestari, P., Prabowo, A., \& Wibowo, A. (2012). Manajemen komunikasi bencana Merapi 2010. Jurnal Ilmu Komunikasi, 10(2), 173-197.

Luna, S., \& Pennock, M. J. (2018). Social media applications and emergency management: A literature review and research agenda. International Journal of Disaster Risk Reduction, 28, 565-577.

Nazaruddin, M. (2013). Natural hazard and semiotic changes on the slope of Mt. Merapi, Indonesia (Master Thesis, University of Tartu, Tartu).

Nazaruddin, M. (2017). Media and visual representation of disaster: Analysis of Merapi eruption in 2010. In R. Djalante, M. Garschagen, F. Thomalla, \& R. Shaw (Eds.), Disaster risk reduction in Indonesia: Progress, challenges, and issues (pp. 307-333). Berlin: Springer. doi: https://doi.org/10.1007/978-3-319-54466-3_12

Nazaruddin, M., \& Habibi, Z. (Eds.) (2012). Jurnalisme warga, radio publik dan peliputan bencana. Yogyakarta: Penerbit Komunikasi UII.

Oliver-Smith, A. (1996). Anthropological research on hazards and disasters. Annual Review of Anthropology, 25, 303-328.

Purworini, D., Purnamasari, D., \& Hartuti, D. P. (2019). Crisis communication in a natural disaster: a chaos theory approach. Jurnal Komunikasi: Malaysian Journal of Communication, 35(2), 35-48.

Rasmussen, J., \& Ihlen, $\varnothing$. (2017). Risk, crisis, and social media: A systematic review of seven years' research. Nordicom Review, 38(2), 1-17. doi: 10.1515/nor-2017-0393.

Rose, G. (2007). Visual methodologies: An introduction to the interpretation of visual materials. London: Sage Publications.

Roskusumah, T. (2013). Komunikasi mitigasi bencana oleh Badan Geologi KESDM di Gunung Api Merapi Prov. D. I. Yogyakarta. Jurnal Kajian Komunikasi, 1(1), 59-68.

Schlehe, J. (1996). Reinterpretation of mystical traditions-explanations of a volcanic eruption in Java. Anthropos, 91(46), 391-409. 
Sudibyakto, Retnowati, A., Suryanti, A. D., \& Hisbaron, D. (2012). Menuju masyarakat tangguh bencana: Tinjauan dari fenomena multi-bencana di Indonesia. In A. Indiyanto \& A. Kuswanjono (Eds.), Konstruksi masyarakat tangguh bencana: Kajian integratif ilmu, agama, dan budaya (pp. 7-32). Bandung: Mizan and CRCS UGM.

Surono, M., Jousset, P., Pallister, J., Boichu, M., Fabrizia, M., \& Buongiorno. (2012). The 2010 explosive eruption of Java's Merapi volcano - A '100-year' event. Journal of Volcanology and Geothermal Research, 241-242, 121-135.

Triyoga, L.S. (2010). Merapi dan Orang Jawa: Persepsi dan Kepercayaannya. Jakarta: Grasindo.

Voight, B., Constantine, E.K., Siswowidjoyo, S., \& Torley, R. (2000). Historical eruptions of Merapi volcano, Central Java, Indonesia. Journal of Volcanology and Geothermal Research, 100, 69-138. 